\title{
Nasopharyngeal Carriage of Potential Pathogenic Bacteria in Healthy Children Living in Istanbul
} Istanbul'da Yaşayan Sağlıkı Çocuklarda Potansiyel Patojen Bakterilerin
Nazofarengeal Taşıyıcılığın Araştırılması

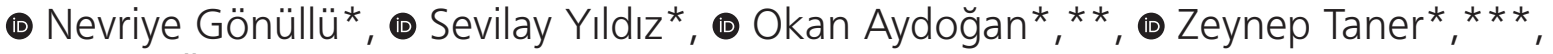 \\ ๑ Sinem Özdemir*, ๑ Selcan Akyol*, ๑ Halit Tokman*, ๑ Fatma Köksal Çakırlar* \\ *istanbul University Cerrahpaşa Faculty of Medicine, Department of Medical Microbiology İstanbul, Turkey \\ **istanbul Medipol University Faculty of Medicine, Department of Medical Microbiology, istanbul, Turkey \\ ***istanbul Altınbaş University Faculty of Medicine, Department of Medical Microbiology Istanbul, Turkey
}

\section{Abstract}

Aim: The purpose of this study was to determine the prevalence of nasopharyngeal carriage of potentially pathogenic bacteria (especially Streptococcus pneumoniae, Haemophilus influenzae, Moraxella catarrhalis) in healthy 1-7 years old children and risk factors affecting it.

Methods: A total of four hundred forty-five healthy children (1-7 years old) from the European side of Istanbul (10 different units) were included in this cross-sectional study. Isolated microorganisms were identified by standard laboratory methods and the results were evaluated. Risk factors affecting the prevalence of nasopharyngeal carriage were also evaluated.

Results: In the study, 139 (31.2\%) of the samples were positive. S. pneumoniae two $(0.4 \%), H$. influenzae 50 (11.2\%); of them type b $10(2.2 \%), H$. parainfluenzae $10(2.2 \%)$, M. catarrhalis 14 (3.1\%), S. aureus 35 (7.9\%), Group A $\beta$ hemolytic streptococci (Streptococcus pyogenes) 13 (2.9\%), Group B streptococci (S. agalactiae) 18 (4.0\%), Non A Non B streptococci 16 (3.6\%) were detected. The results obtained from different sites (places) were found to be variable in terms of pathogen density.

Conclusion: Nasopharyngeal carriage rates found in our study were generally lower than in some studies on this subject. However, when the samples taken from different places were evaluated one by one, it was seen that the colonization rate reached $45.9 \%$ in crowded and poor building properties (small, poorly ventilated, unhealthy buildings). The highest rate of $H$. influenzae carriage in the 2-3 age group was $33.3 \%$. In this study, crowded and unhealthy school environments and low maternal education level have been determined as risk factors for increased nasopharyngeal carriage rate. Results of such studies vary depending on the region, sample frequency, individual and
Amaç: Bu çalışmada sağlıklı 1-7 yaş çocuklarda (Streptococcus pneumoniae, Haemophilus influenzae, Moraxella catarrhalis başta olmak üzere) potansiyel patojen bakterilerin nazofaringeal taşıyıcılık prevalansının ve bunu etkileyen risk faktörlerinin belirlenmesi amaçlanmıştır.

Yöntemler: Bu kesitsel çalışmaya İstanbul Avrupa yakasından (10 farklı birimden) 1-7 yaş grubu toplam dört yüz kırk beş sağlıklı çocuk dahil edildi. İzole edilen mikroorganizmalar standart laboratuvar yöntemleri ile tanımlanarak elde edilen sonuçlar değerlendirildi. Ayrıca, nazofaringeal taşıyıcılık prevalansını etkileyen risk faktörleri değerlendirildi.

Bulgular: Çalışılan örneklerin 139'u $(\% 31,2)$ pozitifti. S. pneumoniae iki $(\% 0,4), H$. influenzae 50 (\%11,2); bunlardan tip b $10(\% 2,2)$, Haemophilus parainfluenzae 10 (\%2,2), $M$. catarrhalis $14(\% 3,1)$, S. aureus $35(\% 7,9)$, A grubu $\beta$ hemolitik streptokok (Streptococcus pyogenes) 13 (\%2,9), B Grubu streptokok (S. agalactiae) $18(\% 4,0)$, Non A Non B streptokok $16(\% 3,6)$ oranlarında tespit edildi. Farklı yerlerden elde edilen sonuçlarda, patojen yoğunluğunun ve çeşitliliğinin değişken olduğu görüldü.

Sonuç: Çalışmamızda tespit edilen nazofaringeal taşıyıcılık oranları bu konuda yapılmış bazı çalışmalara göre düşük bulundu. Ancak örnek alınan farklı kurumlar tek tek değerlendirildiğinde, mevcudu fazla ve bina özellikleri kötü olan yerlerde (kalabalık, küçük, havalandırılması iyi yapılamayan, sağlıksız binalar) oranın \%45,9'a kadar ulaştığı görüldü. H. influenzae taşıyıcılığında ise 2-3 yaş grubunda en yüksek oranı \%33,3 olarak tespit edildi. Bu tür çalışmaların sonuçları bölgeye, örnekleme sıklığına, bireysel ve sosyal faktörlere göre değişiklik göstermektedir. Daha sağlıklı sonuçlara ulaşmak için daha fazla çalışmaya ihtiyaç vardır.
Address for Correspondence/Yazışma Adresi: Okan Aydoğan, İstanbul University Cerrahpaşa Faculty of Medicine, Department of Medical Microbiology İstanbul, Turkey, İstanbul Medipol University Faculty of Medicine, Department of Medical Microbiology İstanbul, Turkey E-mail: okanaydogan4@gmail.com ORCID: orcid.org/0000-0001-7275-8724

Received/Geliş Tarihi: 01 September 2020 Accepted/Kabul Tarihi: 26 November 2020
${ }^{0}$ Copyright 2020 by The Medical Bulletin of istanbul Haseki Training and Research Hospital The Medical Bulletin of Haseki published by Galenos Yayınevi. ${ }^{\circledR}$ Telif Hakkı 2020 istanbul Haseki Eğitim ve Araştırma Hastanesi Haseki Tıp Bülteni, Galenos Yayınevi tarafından yayınlanmıştır. 
social factors. Further studies are needed in order to achieve healthier results.

Keywords: Nasopharyngeal carriage, potential pathogenic bacteria, S. pneumoniae, H. influenzae, M. catarrhalis, vaccinated healthy children, risk factors
Anahtar Sözcükler: Nazofaringeal taşıyıcılık, potansiyel patojen bakteriler, S. pneumoniae, H. influenzae, M. catarrhalis, aşılanmış sağlıklı çocuklar, risk faktörleri

\section{Introduction}

Nasopharynx is heavily colonized by commensal bacteria as well as by a variety of microorganisms, including potential pathogens such as Streptococcus pneumoniae, Haemophilus influenzae (essentially non-typeable strains) and Moraxella catarrhalis. Nasopharyngeal microbiota occurs in the first year after birth, and changes throughout life due to different factors. Carriage rates generally decrease with age. However, these rates are also high in adults with chronic respiratory diseases. Reported nasopharyngeal carriage rates of potentially pathoge, nic bacteria vary widely between different studies and geographic regions. There are a lot of parameters including genetic factors and socio-economic conditions, access to health services, poor hygiene, number of family members, household crowding, access to health services, number of siblings, vaccination, age, type of child care, acute respiratory disease, and sleeping position (1). In Turkey, pneumococcal conjugate vaccine pneumococcal vaccine (PCV) 7 was introduced into the national immunization program in 2008, with a switch to PCV13 in 2011; the vaccination rate is estimated to be higher than $95 \%$ for children $<2$ years of age and it begins at 2 months of age with the other doses at 4 and a booster dose at 12 months. $H$. influenzae type b (Hib) vaccination is performed also at 2, 4 and 6 months of age with a booster at 18 months. Different results have been reported from different countries, and the different regions of Turkey about the rate of nasopharyngeal carriage of potentially pathogenic bacteria (1-3). In this study, we aimed to determine the rates of nasopharyngeal colonization of potential respiratory pathogens isolated from healthy school children vaccinated in Istanbul and some risk factors for nasopharyngeal carriage.

\section{Methods}

This cross-sectional study was conducted between 2014 and 2017 (sample collection, February-April 2016). The study involved four hundred forty-five children aged 1-7 years, asymptomatic, who had not taken antibiotics in the past 15 days, and were vaccinated in ten different institutions in the European side of İstanbul. Sociodemographic characteristics of the children (age, gender, number of household members, average income, etc.) and situations that may be risk factors for carriage (antibiotic use in the past month, number of people sharing the same room in the family, presence of siblings under the age of 5, exposure to smoke at home, etc.) were questioned.

Nasopharyngeal samples were collected using cotton tipped swabs and immediately transferred into transport medium and delivered to the laboratory. On the same day, 5\% sheep blood agar and chocolate agar (Becton Dickinson, USA) were cultured by single colony method. After 24 hours of incubation at $37^{\circ} \mathrm{C}$, Gram staining was performed from suspicious colonies that grew. Standard tests were applied for identification. For the detection of Streptococcus, bacteria displaying beta hemolysis ( $\beta$-hemolysis) were first identified by classical methods. Group identifications were performed using bacitracin (0.04 units), trimethoprim $(1.25 \mu \mathrm{g})$-sulfamethoxazole $(23.75 \mu \mathrm{g})$ discs and commercial latex agglutination kits (Dryspot Streptococcal Grouping Kit-Oxoid, England). Bacitracin-sensitive and trimethoprim-sulfamethoxazoleresistant ones were accepted as Group A beta-hemolytic streptococci (GABHS). Catalase test was applied for differentiation between streptococcus and staphylococcal microorganisms with similar hemolysis properties. In vitro coagulase test to determine the pathogenicity of growing staphylococci, optochin susceptibility test and bile dissolution tests to distinguish pneumococci were performed. $H$. influenzae needs both $X$ and $V$ factors simultaneously. With this feature, diagnosis was made. Typing was done by slide agglutination using antiserum specific for Hib (Denka SeikenTM, Japan). Biochemical properties of the growing Gram-negative bacilli were also examined and detected. Identification of $S$. aureus isolates was performed according to standard microbiological procedures (morphology, Gram stain, catalase test, coagulase test, mannitol salt agar fermentation).

This research study was approved by the istanbul University-Cerrahpaşa Faculty of Medicine Ethics Committee of Clinical Research (approval no: A-12/07 Jan 2014). Written informed consent was obtained from all of the parents of children who participated in the study. 
Necessary permissions were obtained from the istanbul Governorship, the Provincial Health Directorate and the Provincial Directorate of National Education for the study.

\section{Results}

Four hundred forty-five healthy children, including two hundred three girls (45.6\%) and two hundred fortytwo boys (54.4\%), aged 1-7 years were included in the study. The number of positive specimens was a hundred thirty-nine (31.2\%), and the carriage rate was $48 \%$ in girls and $52 \%$ in boys. Eleven bacteria species were isolated in the study. Potential pathogenic bacteria isolated from nasopharyngeal specimens are given below (Table 1, 2).

In this study, samples from 10 different educational institutions (10 different groups) were collected. The results obtained for five types of bacteria from each of these are given in Figure 1. It was observed that the obtained positivity rates and microorganism distributions differ between institutions. The results show that the carriage rates have increased significantly in crowded places. The positivity rate reached $45.8 \%$ in a crowded school. The carriage rates were between $12.5 \%$ and $45.8 \%$ in different institutions. $H$. influenzae was the most commonly detected microorganism with $33.3 \%$ in children aged 2-3 years in a nursery. Gender, exposure to

\begin{tabular}{|c|c|c|}
\hline $\begin{array}{l}\text { Distribution } \\
\text { types }\end{array}$ & Microorganisms & n (\%) \\
\hline 1 & H. influenzae & $36(8.9)$ \\
\hline 2 & H. influenzae $+S$. aureus & $3(0.7)$ \\
\hline 3 & H. influenzae + S. pyogenes & $4(0.9)$ \\
\hline 4 & H. influenzae + non-A non-B Streptococci & $4(0.9)$ \\
\hline 5 & H. influenzae + group B Streptococci & $1(0.2)$ \\
\hline 6 & $\begin{array}{l}\text { H. influenzae + non-A non-B Streptococci + } \\
\text { S. aureus }\end{array}$ & $2(0.4)$ \\
\hline 7 & H. parainfluenzae & $8(1.8)$ \\
\hline 8 & H. parainfluenzae $+S$. aureus & $2(0.4)$ \\
\hline 9 & S. aureus & $25(5.6)$ \\
\hline 10 & S. aureus + Pseudomonas & $1(0.2)$ \\
\hline 11 & M. catarrhalis & $12(2.7)$ \\
\hline 12 & M. catarrhalis $+S$. aureus & $2(0.4)$ \\
\hline 13 & S. pyogenes & $9(2.0)$ \\
\hline 14 & non-A non-B Streptococci & $10(2.2)$ \\
\hline 15 & Group B Streptococci & $16(3.6)$ \\
\hline 16 & Group B Streptococci + S. aureus & $1(0.2)$ \\
\hline 17 & S. pneumoniae & $2(0.4)$ \\
\hline 18 & Acinetobacter & $1(0.2)$ \\
\hline 19 & E. coli & $1(0.2)$ \\
\hline \multicolumn{3}{|l|}{$\mathrm{n}$ : Number } \\
\hline
\end{tabular}

the negative effects of cigarette smoke (passive smoking), crowded household and recent respiratory infections do not constitute important risk factors for carriage; however, low maternal education level, and crowded and unsuitable school environments were found to be risk factors that increase carriage. There was no significant difference between the socio-economic levels of the groups. The characteristic features of the study group are given in Table 3.

\begin{tabular}{|l|l|l|}
\hline \multicolumn{3}{|l|}{ Table 2. Microorganisms isolated from nasopharyngeal samples } \\
\hline Bacteria types & Microorganisms & $\mathbf{n}(\%)$ \\
\hline 1 & H. influenzae & $50(11.2)$ \\
\hline 2 & H. parainfluenzae & $10(2.2)$ \\
\hline 3 & M. catarrhalis & $14(3.1)$ \\
\hline 4 & S. pneumoniae & $2(0.4)$ \\
\hline 5 & S. aureus & $35(7.9)$ \\
\hline 6 & S. pyogenes & $13(2.9)$ \\
\hline 7 & Group B Streptococci & $18(4.0)$ \\
\hline 8 & Non-A Non-B Streptococci & $16(3.6)$ \\
\hline 9 & Acinetobacter & $1(0.2)$ \\
\hline 10 & Pseudomonas & $1(0.2)$ \\
\hline 11 & E. coli & $1(0.2)$ \\
\hline n: Number & & \\
\end{tabular}
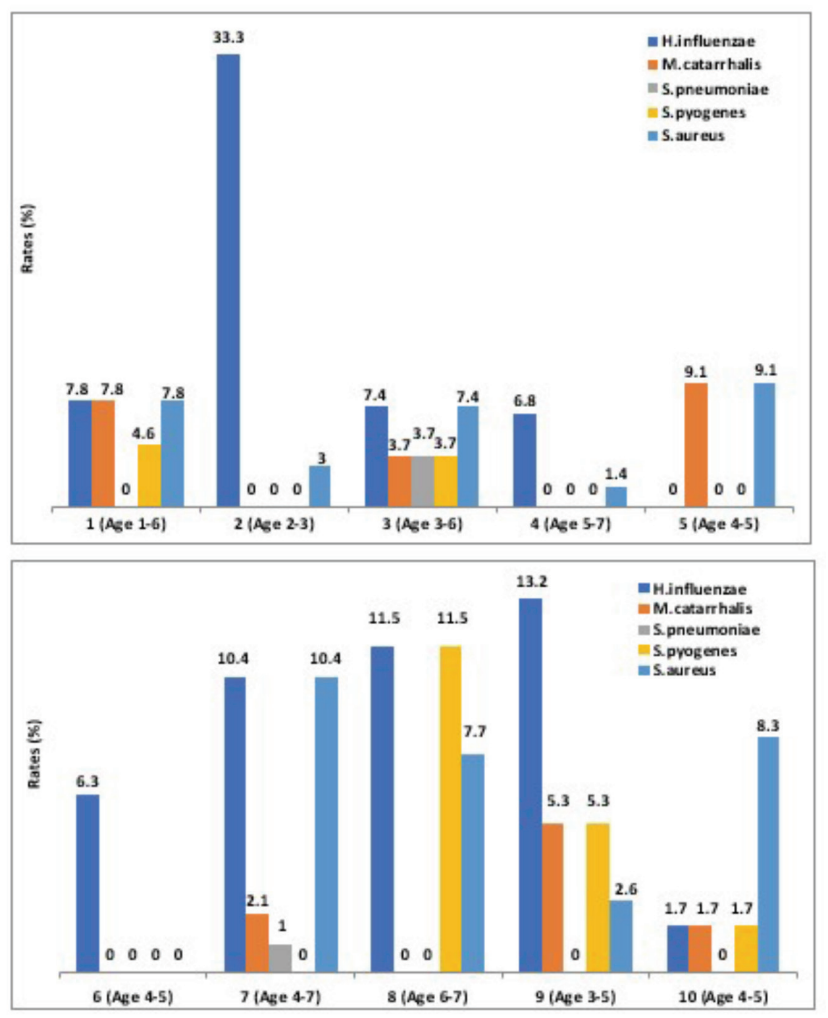

Figure 1. Carriage percentages of five bacteria in ten different educational institutions 


\section{Discussion}

For hundred and forty-five healthy children aged 1-7 years from 10 different places (nursery, kindergarten and primary school 1st grade) were included in the study. According to the results we have achieved; the total nasopharyngeal carriage rate for 11 types of potential respiratory pathogens was $31.23 \%$ : S. pneumoniae $0.44 \%, H$. influenzae $11.23 \%$; type b $2.24 \%$, $H$. parainfluenzae $2.24 \%$, M. catarrhalis $3.14 \%$, S. aureus $7.86 \%$, S. pyogenes $2.92 \%$. It is seen that the results

\begin{tabular}{|c|c|}
\hline Characteristics $(n=445)$ & Number (\%) \\
\hline \multicolumn{2}{|l|}{ Sex } \\
\hline Male & $242(54.4)$ \\
\hline Female & $203(45.6)$ \\
\hline \multicolumn{2}{|l|}{ Age } \\
\hline $1-7$ & $445(100)$ \\
\hline \multicolumn{2}{|l|}{ Education of mother } \\
\hline High & $98(22)$ \\
\hline Low & $347(78)$ \\
\hline \multicolumn{2}{|c|}{ Number of people at home } \\
\hline$\leq 3$ & $136(30.6)$ \\
\hline$\geq 3$ & 309 (69.4) \\
\hline \multicolumn{2}{|c|}{ Exposure to smoke at home } \\
\hline Yes & $254(57.1)$ \\
\hline No & $191(42.9)$ \\
\hline \multicolumn{2}{|l|}{ Family economic status } \\
\hline Low & - \\
\hline Medium & $445(100)$ \\
\hline High & - \\
\hline $\mathrm{n}$ : Number & \\
\hline
\end{tabular}

about multiple bacteria colonization were obtained only in a small number of publications and they are different from each other $(2,4-6)$. This situation can be attributed to the effect of many factors on nasopharyngeal carriage (1).

The distribution of the pathogens are shown in Table 4 and compared with other studies' findings.

Torun et al. (2) conducted a study with 330 healthy children in the 6-10 age group in istanbul and they found $H$. influenzae in $48.7 \%$, type b $7.2 \%$, S. pneumoniae in $29.1 \%$, and $M$. catarrhalis in $23.9 \%$. This study is most suitable for comparing our results with the situation in previous years. However, given the possible differences in risk factors, healthy comparisons cannot be made.

Principi et al. (4) conducted a study with a thousand seven hundred twentythree children aged 1-7 years from eighteen schools and day care centers in eighteen Italian cities. They found that the rate of carriage respiratory pathogens was $17.9 \%$ (S. pneumoniae 3.5\%, $H$. influenzae $11.9 \%, M$. catarrhalis 4.1\%). Especially in children aged 1-5, siblings under 3 years of age, living in rural areas and staying in a full-day care home significantly affect carrier rates; however, they found that breastfeeding, gender, passive smoking, and recent respiratory infections were not significant variables. In this study, it was reported that antibiotic treatment in the previous three months did not affect nasopharyngeal carriage and S. pneumoniae carriage was associated with recurrent macrolide treatment.

In Belgium, a study with three hundred thirthy three healthy children of different socio-economic levels aged 3-6 point out that $50 \%$ of children were colonized at least once with S. aureus, $69 \%$ with S. pneumoniae, $67 \%$ with M. catarrhalis and it was found that $83 \%$ of them were colonized with $H$. influenzae (5).

\begin{tabular}{|c|c|c|c|c|c|c|c|c|c|}
\hline Study (Reference) & Country & $\mathbf{n}$ & $\begin{array}{l}\text { S. pneumoniae } \\
(\%)\end{array}$ & $\begin{array}{l}H . \\
\text { influenza } \\
(\%)\end{array}$ & $\begin{array}{l}\text { H. } \\
\text { influenza } \\
\text { type B (\%) }\end{array}$ & $\begin{array}{l}\text { H. } \\
\text { parainfluenza } \\
(\%)\end{array}$ & $\begin{array}{l}\text { M. } \\
\text { catarrhalis } \\
(\%)\end{array}$ & $\begin{array}{l}\text { S. } \\
\text { aureus } \\
(\%)\end{array}$ & $\begin{array}{l}\text { S. } \\
\text { pyogenes } \\
(\%)\end{array}$ \\
\hline Our Study & Turkey & 445 & 0.44 & 11.23 & 2.24 & 2.24 & 3.14 & 7.86 & 2.92 \\
\hline Torun et al. (2) & Turkey & 330 & 29.1 & 48.7 & 7.2 & - & 23.9 & - & - \\
\hline Principi et al. (4) & Italy & 1723 & 3.5 & 11.9 & - & - & 4.1 & - & - \\
\hline Jourdain et al. (5) & Belgium & 333 & 67 & - & - & - & 83 & 69 & - \\
\hline Dunne et al. (6) & Indonesia & 302 & 49.5 & 27.5 & - & - & 42.7 & 7.3 & - \\
\hline Abaye et al. (8) & Ethiopia & - & 18.4 & - & - & - & - & - & - \\
\hline Wada et al. (9) & Ethiopia & - & 43.8 & - & - & - & - & - & - \\
\hline Claire et al. (11) & Kenya & 323 & $19.4-20.0$ & - & - & - & - & - & - \\
\hline Birindwa et al. (12) & Congo & 794 & 21 & - & - & - & - & - & - \\
\hline Koliou et al. (13) & Cyprus & 402 & 35.3 & - & - & - & - & - & - \\
\hline Yang et al. (16) & China & 17338 & - & 17.1 & - & - & - & - & - \\
\hline Ortiz-Romero et al (17) & Spain & 404 & - & - & - & - & - & - & - \\
\hline Toprak et al. (21) & Turkey & 1129 & - & - & - & - & - & - & 6.5 \\
\hline
\end{tabular}


In a study conducted by Dunne et al. (6) with three hundred two healthy children aged 12-24 months, the carriage prevalence was $49.5 \%$ for S. pneumoniae, $27.5 \%$ for $H$. influenzae, $42.7 \%$ for $M$. catarrhalis and $7.3 \%$ for S. aureus.

In our country, studies conducted in Istanbul in recent years showed that the rate of $S$. pneumoniae carriage varies depending on age and the rates decreased after vaccination $(3,7)$.

Arvas et al. (3) found $14 \%$ S. pneumoniae carriage in their study with a hundred fifty vaccinated healthy children (in 2014) aged 0-6 in istanbul. However, the rate of $S$. pneumoniae carriage in young children of 24 months has been reported to be $76.2 \%$. The low, $0.44 \%$, S. pneumoniae rate detected in our study suggests that other factors may also be effective. In our study, this can be attributed to the fact that the number of children under 2 was quite low.

In a study by Soysal et al. (7), the low prevalence of pneumococcal carriage was remarkable. Soysal et al. (7) determined the prevalence of pneumococcal carriage as $6.4 \% 5$ years after PCV-7 vaccination and 2 years after PCV-13 childhood vaccination in 2,165 healthy children in the 0-18 age group in Istanbul between 2011 and 2013.

In recent years, there are important findings related to pneumococcal carriage risk factors in studies conducted abroad: the number of siblings under certain ages, sleeping in the same room, crowded family environment, young age, mothers with low education level and low socioeconomic status were found to be related to carriage (8-10).

In their study including children aged $\leq 6$ years, Abaye et al. (8) found a general pneumococcal carriage rate of $18.4 \%$. It was determined that there was no significant variation in colonization according to gender and age of children. Children living with younger siblings $(1-2<6$ years) and number of persons $>5$ in the household were associated with higher rates of $S$. pneumoniae carriage.

Wada et al. (9) found a S. pneumoniae carriage rate of $43.8 \%$ in seven hundred fourteen children aged 3-13 years. The rate was determined as $62.5 \%$ in $3-5$ years old children and $38.6 \%$ in 6-13 years old children. Sleeping with siblings and age below five years were significantly associated with $S$. pneumoniae carriage. Findings of Fadlyana et al. (10) emphasized the association of the level of maternal education and socio-economic factors with nasopharyngeal carriage. Having more than one small child in the household has been identified as a risk factor for transport of potential pathogenic bacteria. There was no difference in the frequency of carriage of $S$. pneumoniae, $H$. influenzae, $M$. catarrhalis and $S$. aureus among urban and semi-rural children. Low maternal education level is also valid for our study group as a risk factor that increases carriage.

Some publications suggest that vaccination affects the overall prevalence of pneumococcal carriage, and among other known risk factors, the prevalence of serotypes included in the vaccine (vaccine strains) is lower in vaccinated children and the prevalence is higher in children without vaccination and in poor living conditions (11-13). It has been reported that pneumococcal conjugate vaccines could have a protective effect against colonization by drug-resistant pneumococcal strains (1113).

Claire et al. (11) determined in a study with nasopharyngeal swab samples from 323 children aged 4-7 years from coastal Kenya before and after vaccination with 10-valent pneumococcal vaccine, it was found that vaccination did not decrease the overall prevalence of pneumococcal carriage; the number of colonized children before vaccination was $65(20 \%)$ and the number of colonized children after vaccination was 63 (19.4\%). However, they determined that the prevalence of serotypes (vaccine strains) included in the vaccine decreased from $43 \%$ to $19 \%$.

In 2014 and 2015 Birindwa et al. (12) investigated, pneumococcal carriage in seven hundred ninety fdur healthy children aged 1 to 60 months who attended health centers in the east part of Congo and who were vaccinated with a 13-valent conjugated PCV13 in 2013. According to their results, the rate of pneumococcal carriage was $21 \%$. They found that the rate of carriage was higher in children who had not received PCV13 vaccination, lived in rural areas, in a house without an enclosed kitchen, malnourished and had high fever. It is stated that the results show that in addition to PCV13 vaccination, better living conditions are needed to reduce pneumococcal burden. In the study, worryingly decreased susceptibility to commonly used antibiotics for pneumococci infections and need for more appropriate use of antibiotics in the region were highlighted.

Koliou et al. (13) found that $35.3 \%$ of the children were colonized with $S$. pneumoniae in a study they conducted with four hunred two healthy children aged 6 months- 5 years in Cyprus. Attending a day-care center has been identified as a risk factor that increases colonization approximately by 3 times. They stated that factors such as age, gender, breastfeeding history and passive exposure to cigarette smoke were not statistically significantly related to the risk of $S$. pneumoniae colonization. On the other hand, complete vaccination with PCV7 has been shown to have a protective effect against colonization compared to unvaccinated children (the risk decreased two times). 


\section{Conclusion}

It has been stated that the careful use of antibiotics for upper respiratory tract infections, especially in children, and increasing the coverage of pneumococcal conjugate vaccines can be effective in reducing levels of colonization by drug-resistant pneumococcal strains.

In our study, the $H$. influenzae carriage rate was $11.23 \%$, while in Italy, it was $14.1 \%(14)$ in a study involving seven hundred seventeen healthy children $<6$ years of age, 15 years after vaccination of Hib. On the other hand, in a study conducted in Spain, it was found that $42 \%$ of 960 healthy $<5$ years old children were colonized with $H$. influenzae and the rate varied between centers (12$83 \%)(15)$. In our study, it was determined that there was variability among institutions (0-33.3\%).

$H$. influenzae carriage rate was determined to be $17 \%$ in children in a study in which a total of 42 studies with 17,388 participants were included in China. It was reported that the rate was relatively low in healthy population, but showed great differences between provinces (16). This study also explains the differences in carriage rates.

Ortiz-Romero et al. (17) performed a study with four hundred four healthy children $<5$ years of age in Spain and determined the rate of $H$. influenzae carriage as $73.2 \%$ in winter and $26.8 \%$ in summer.

As a result, according to our findings, Haemophilus influenzae carriage rates vary depending on factors such as study region, centers, seasons (15-17).

Staphylococcus aureus carriage rates are known to vary by country, demographic group and occupation $(5,18)$.

Streptococcus agalactiae, known as group B Streptococcus GBS, is an important cause of neonatal sepsis and meningitis (19). In our study, $4.04 \%$ of carriers were detected to have this bacterium. The natural reservoir for GABHS is humans. They are the most common cause of streptococcal pharyngitis. It is generally seen in school age children at the ages of 5-15 (20). Toprak et al. (21) detected $6.5 \%$ S. pyogenes carriage in $6.5 \%$ of 1,129 primary school children in the 7-15 age group in the city center of Afyonkarahisar. Tonsillopharyngitis developed in $5.5 \%$ of the children within a year. In our study, S. pyogenes carriage rate was found to be $2.9 \%$. However, in one group (6-7 years) the rate was $11.5 \%$.

When looking at the results obtained from different places in different studies, the differences between them (carriage rates and microorganism diversity, etc.) are thought-provoking. In order to minimize the health problems associated with carriage, there is a need for new studies in which the determination of carriage rates will be handled together with risk factors.

It is an advantage of our study that this study was not performed in a single center. We observed that the carriage prevalence varies considerably between institutions. At the same time, the change in the diversity of microorganisms has emerged strikingly. Low maternal education level and crowded classroom environments were found to increase the prevalence of nasopharyngeal carriage. Especially S. pneumoniae carriage rate was very low. Among the possible reasons for this result; the age of the children in our study (scarcely any number of children under the age of 2) and their vaccination are important. Besides, the leading factors affecting the results are: there was no significant difference in the socio-economic status which was at a good level, between the families, and the children could benefit from health services adequately and correctly.

\section{Authorship Contributions}

Concept: N.G., S.Y., O.A., Z.T., S.Ö., S.A., H.T., F.K.Ç. Design: N.G., S.Y., O.A., Z.T., S.Ö., S.A., H.T., F.K.Ç. Data Collection or Processing: N.G., S.Y., O.A., Z.T., S.Ö., S.A., H.T., F.K.Ç. Analysis or Interpretation: N.G., S.Y., O.A., Z.T., S.Ö., S.A., H.T., F.K.Ç. Literature Search: N.G., S.Y., O.A., Z.T., S.Ö., S.A., H.T., F.K.Ç. Writing: N.G., S.Y., O.A., Z.T., S.Ö., S.A., H.T., F.K.Ç

Conflict of Interest: The authors have no conflict of interest.

Financial Disclosure: This study was supported by Istanbul University Scientific Research Projects Unit (Project No: 41683).

\section{References}

1. García-Rodríguez JÁ, Fresnadillo Martínez MJ. Dynamics of nasopharyngeal colonization by potential respiratory pathogens. J Antimicrob Chemother 2002;50(Suppl S2):5973.

2. Torun MM, Namal N, Demirci M, Bahar H. Nasopharyngeal carriage and antibiotic resistance of Haemophilus influenzae, Streptococcus pneumoniae and Moraxella catarrhalis in healthy school children in Turkey. Indian J Med Microbiol 2009;27:86-8.

3. Arvas A, Çokuğraş H, Gür E, Gönüllü N, Taner Z, Tokman HB. Pneumococcal nasopharyngeal carriage in young healthy children after pneumococcal conjugate vaccine in Turkey. Balkan Med J 2017;34:363-6.

4. Principi N, Marchisio P, Schito GC, Mannelli S. Risk factors for carriage of respiratory pathogens in the nasopharynx of healthy children. Ascanius Project Collaborative Group. Pediatr Infect Dis J 1999;18:517-23.

5. Jourdain S, Smeesters PR, Denis O, et al. Differences in nasopharyngeal bacterial carriage in preschool children from different socio-economic origins. Clin Microbiol Infect 2011;17:907-14.

6. Dunne EM, Murad C, Sudigdoadi S, et al. Carriage of Streptococcus pneumoniae, Haemophilus influenzae, 
Moraxella catarrhalis, and Staphylococcus aureus in Indonesian children: a cross-sectional study. PLoS One 2018;13:e0195098.

7. Soysal A, Karabağ-Yılmaz E, Kepenekli E, et al. The impact of a pneumococcal conjugate vaccination program on the nasopharyngeal carriage, serotype distribution and antimicrobial resistance of Streptococcus pneumoniae among healthy children in Turkey. Vaccine 2016;34:3894900.

8. Abaye G, Fekadu H, Haji K, Alemu D, Anjulo AA, Yadate DT. Prevalence and risk factors of pneumococcal nasopharyngeal carriage in healthy children attending kindergarten, in district of Arsi Zone, South East, Ethiopia. BMC Res Notes 2019;12:253.

9. Wada FW, Tufa EG, Berheto TM, Solomon FB. Nasopharyngeal carriage of Streptococcus pneumoniae and antimicrobial susceptibility pattern among school children in South Ethiopia: post-vaccination era. BMC Res Notes 2019;12:306.

10. Fadlyana E, Dunne EM, Rusmil K, et al. Risk factors associated with nasopharyngeal carriage and density of Streptococcus pneumoniae, Haemophilus influenzae, Moraxella catarrhalis, and Staphylococcus aureus in young children living in Indonesia. Pneumonia (Nathan) 2018;10:14.

11. Claire J. Heath CJ, Nayakwadi-Singer $M$, King $C H$, et al. Nasopharyngeal carriage of Streptococcus pneumoniae in children in coastal Kenya. Am J Trop Med Hyg 2018;98:104650.

12. Birindwa AM, Emgård $M$, Nordén $R$, et al. High rate of antibiotic resistance among pneumococci carried by healthy children in the eastern part of the Democratic Republic of the Congo. BMC Pediatrics 2018;18:361.

13. Koliou MG, Andreou K, Lamnisos D, et al. Risk factors for carriage of Streptococcus pneumoniae in children. BMC Pediatr 2018;18:144.
14. Giufre M, Daprai L, Cardines R, et al. Carriage of Haemophilus influenzae in the oropharynx of young children and molecular epidemiology of the isolates after fifteen years of $\mathrm{H}$. influenzae type b vaccination in Italy. Vaccine 2015;33:622734.

15. Puig C, Marti S, Fleites A, et al. Oropharyngeal colonization by nontypeable Haemophilus influenzae among healthy children attending day care centers. Microb Drug Resist 2014;20:4505.

16. Yang $P$, Zhang J, Peng A. The pharyngeal carriage of Haemophilus influenzae among healthy population in China: a systematic review and meta-analysis. BMC Infect Dis 2019;19:547.

17. Ortiz-Romero MDM, Espejo-García MP, Alfayate-Miguelez S, Ruiz-López FJ, Zapata-Hernandez D, Gonzalez-Pacanowska AJ. A Study in the Mediterranean Coast Region. Pediatr Infect Dis J 2017;36:919-23.

18. DP Kateete, BB Asiimwe, R Mayanja, et al. Nasopharyngeal carriage, spa types and antibiotic susceptibility profiles of Staphylococcus aureus from healthy children less than 5 years in Eastern Uganda. BMC Infect Dis 2019;19:1023.

19. Foster-Nyarko E, Kwambana B, Aderonke O, et al. Associations between nasopharyngeal carriage of Group B Streptococcus and other respiratory pathogens during early infancy. BMC Microbiol 2016;16:97.

20. Gram-positive cocci. In Koneman's Color atlas and textbook of diagnostic microbiology. 6th ed. Philadelphia. Lippincott Williams and Wilkins. 2006. p. 672-764.

21. Toprak D, Demirdal T, Aşçı Z, Orhan S, Çetinkaya Z, Demirtürk N. Sağlıklı Okul Çocuklarında Nazofarinksde A Grubu Beta Hemolitik Streptokok Taşıyıcılığı. Duzce Med J 2008;2:26-9. 